\title{
Metastatic Mixed Germ Cell Tumor Presented With Hemoptysis- A Case Report
}

\author{
Sardar Rezaul Islam ${ }^{1 *}$, Maruf Raza ${ }^{2}$, Shah Alam Sarkar ${ }^{3}$, Shah Poran ${ }^{4}$, Mushfiqur Rahman ${ }^{4}$ \\ ${ }^{1}$ Professor and Head, Department of Surgery, Imperial hospital, (IHL) Chattogram. \\ ${ }^{2}$ Associate Professor and Head, Department of pathology, Jahurul Islam Medical College (JIMC), Bajitpur, Kishoreganj. \\ ${ }^{3}$ Registrar, Department of surgery, IHL. \\ ${ }^{4}$ Registrar, Department of Surgery, JIMC
}

*Corresponding author: Sardar Rezaul Islam, Professor and Head, Department of Surgery, Imperial hospital, (IHL) Chattogram: E-Mail: islamreza@hotmail.com

Received Date January 20, 2020; Accepted Date: January 28, 2020; Published Date: January 31, 2020.

Citation: Sardar Rezaul Islam. (2020) Metastatic Mixed Germ Cell Tumor Presented With Hemoptysis- A Case Report.journal of Surgical Case Reports and Images, 3(1): Doi: 10.31579/2690-1897/017

Copyright: (C) 2020. Sardar Rezaul Islam. This is an open-access article distributed under the terms of the Creative Commons Attribution License, which permits unrestricted use, distribution, and reproduction in any medium, provided the original author and source are credited.

\begin{abstract}
A 35 year's old male presented with right testicular swelling for last six month. He developed hemoptysis and mild dyspnea for 2 weeks. Ultrasonography revealed testicular malignancy with multiple heterogenecity. CT scan of the abdomen did not reveal any lymph node metastasis. His X-ray chest showed extensive pulmonary metastasis. All three tumor markers were raised. Histology was suggestive of mixed germ cell tumor with a rare combination of Seminoma and Choriocarcinoma. Because of this rare combination of 2 varieties of testicular germ cell tumor and advanced systemic metastasis we presented this case.

Key words: testicular cancer; mixed germ cell tumor; seminoma; choriocarcinoma; pulmonary metastasis; hemoptysis
\end{abstract}

\section{Introduction}

Primary testicular tumors are the most common solid malignant tumor in men between the ages of 20 and 35 years. For unknown reasons, the incidence of this cancer has increased during the last century.

Most testicular tumors are derived from the germ cells of the testis, although about $5 \%$ of testicular tumors are derived from other cells, including Leydig cells and lymphocytes (lymphoma).

The cause of testicular tumors is unknown, but several predisposing factors are recognized. Cryptorchidism, genetic susceptibility, family history, and past history of testis cancer have been reported as the important risk factors. Their incidence has increased over the past century. Ninety-five percent of testis tumors originate from germ cells while the remaining 5\% are Leydig cell tumors and lymphomas (1). Germ cell tumors can be broadly classified as seminomatous and nonseminomatous. Approximately $60 \%$ of germ cell tumors are mixed germ cell tumors (2). Painless swelling or nodule in testis is usually the most common symptom. However, metastasis-related symptoms may be the first presenting symptom (3). We report a patient diagnosed with mixed germ cell tumor presenting with hemoptysis and mild dyspnea due to massive lung metastasis.

Any solid, firm mass within the testis should be considered testicular cancer until proven otherwise. Prompt diagnosis and early treatment are required for cure. Testicular cancer may be painless, in which case they are sometimes ignored by the patient. In patients with scrotal pain, testicular cancer must be differentiated from epididymo-orchitis. The clinician should consider the full differential diagnosis of a testicular mass, which includes epididymo-orchitis, testicular torsion, hydrocele, hernia, hematoma, spermatocele, varicocele, and syphilitic gumma.
In the past, metastatic testicular cancer was usually fatal, but recent advances in treatment, including high-dose chemotherapy and stem cell rescue, have considerably improved the prognosis. Indeed, testicular cancer is a bright spot in the oncological landscape and are now considered to be the model for treatment of solid tumors.

\section{Case Presentation}

A 35 years old male presented with six month history of painless swelling of the right testis. He ignored this swelling. He developed hemoptysis and mild dyspnea for two weeks. He did not complain of any abdominal pain. On examination his right testis was swollen, firm to hard in consistency and having smooth surface. It was oval in shape but size was about $8 \mathrm{~cm} / 5$ $\mathrm{cm}$ (Fig-1). The testis was not fixed with the scrotal wall. Ultrasonography showed a right testicular mass with multiple heterogenecity. There was no fluid collection in the scrotum. CT scan of the abdomen did not reveal any lymph node enlargement. His chest x-ray showed an extensive multiple cannon ball appearance on both lung fields (Fig-2). His serum marker was done. His $\alpha$-feto protein was $>1000 \mathrm{U} / \mathrm{ml}$ (range0.5-5U/ml) B-HCG was 399U/L (normal<10 IU/L), and LDH was 923 U/L (normal226-450U/L). Right radical orchiectomy was done. Histology of the tumor showed mixed germ cell tumor of testis with multiple components. Microscopy revealed a combination of Seminoma and Choriocarcinoma. His hemoptysis stopped after radical

Orchiectomy. Patient was sent to oncologist for further chemotherapy and radiotherapy. 


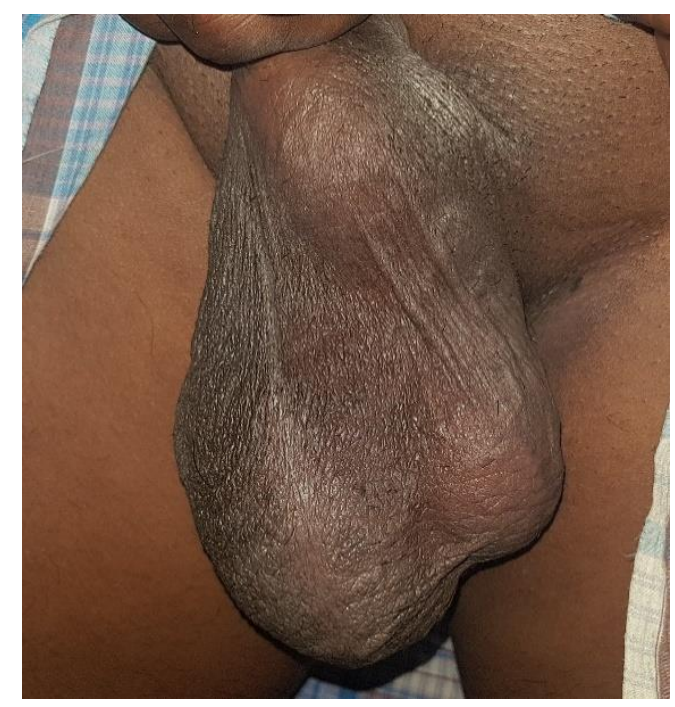

Fig1

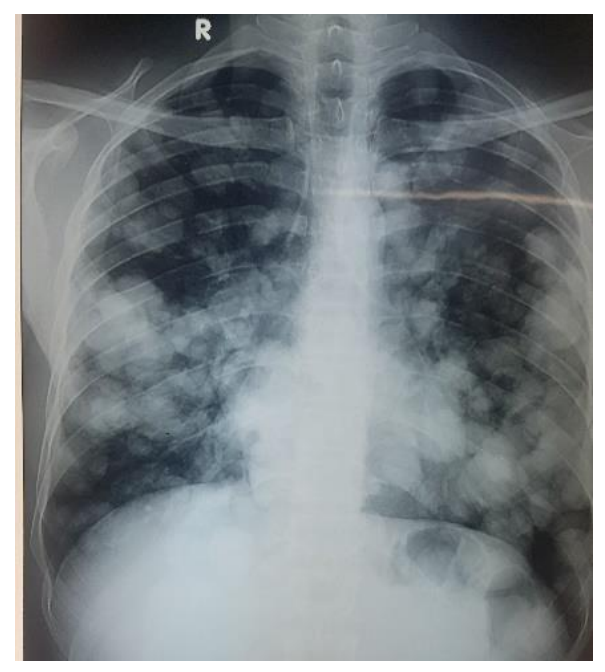

Fig-2

\section{Discussion}

Non-seminomatous germ cell tumors are highly aggressive malignancies of the testis. Histologically, approximately $70 \%$ of the non-seminomatous germ cell tumors are composed of more than one germ cell component, which is called mixed germ cell tumor. Several studies have reported specific combinations of different elements in mixed GCT of testis $[4,5]$. Mostofi [5] in classifying more than 6000 testicular tumors found $>1$ histological patterns in approximately $60 \%$ of cases with the most frequent combination of embryonal carcinoma, yolk sac tumor and choriocarcinoma. Statistical analysis of possible combinations by Mosharafa et al. revealed 10 possible pair combinations. Complete diagnosis requires obtaining an appropriate specimen for making the correct diagnosis together with the correlation of the serum tumor markers. This is important for staging and also for postoperative follow up and to know the response of the treatment and surveillance. $\alpha$ fetoprotein (AFP) is produced by the yolk sac elements and is elevated in $50-70 \%$ of NSGCT. It is not usually elevated in pure seminoma. Its halflife is about 5 days. $\beta$-human chorionic gonadotrophin ( $\beta$-HCG) is produced by trophoblastic elements in the tumor. It is raised in 40 to $60 \%$ of NSGCTs and in up to $30 \%$ of pure seminomas. It has a half-life of 1 day. Lactate dehydrogenase (LDH) is less specific, but is more common in seminoma. Overall, $90 \%$ of NSGCTs elaborate at least one tumor marker, while markers are elevated in $<40 \%$ of seminomas. This patient had all three markers substantially raised.

Choriocarcinoma is relatively rare among the various components of nonseminomatous germ cell tumors, including embryonal carcinoma, seminoma, yolk sac tumor and teratoma. Less than $8 \%$ of the testicular germ cell tumors contain a choriocarcinoma component, and pure choriocarcinoma accounts for only $0.3 \%$ of all the primary testicular germ cell tumors [6].

The term choriocarcinoma is generally used to refer to gestational choriocarcinoma, which most commonly occurs with hydatidiform mole. It is a cancer that typically occurs in the chorionic epithelium of the placenta of females and it rarely occurs in males. Choriocarcinoma in the testis has a particularly high-risk histology and the patients with this tumor are prone to present with metastases rather than a testicular mass. The most common presenting symptoms include hemoptysis secondary to pulmonary metastases, back pain secondary to retroperitoneal spread, gastrointestinal bleeding due to gastrointestinal tract metastases and neurological symptoms that are due to brain metastases [7].

Yokoi $\mathrm{K}$ et al. recently reported a review of the literature on choriocarcinoma [6]. They examined the characteristics of this tumor based on 106 cases of male choriocarcinoma that were reported during the previous 12 years (1995 to 2005). The testis was the most common primary site at $33 \%$ (35/106), followed by the mediastinum, pineal body, gastrointestinal tract, lung and retroperitoneum. Metastasis was seen in $83 \%$ of the patients, with multiple metastases seen in most of the patients. The most common metastatic sites were the lung, liver and brain. The mean age of the males with choriocarcinoma was 36.0 years, and this tumor tended to occur in children and adolescent, where the age of two thirds of all the cases (69/106) was less than 30-years old. The prognosis of male choriocarcinoma was very poor, with the cumulative survival rate being $30 \%$, and the course of the disease was rapid with the mean survival time being 7.7 months; $23.8 \%$ and $45.4 \%$ of the patients showed 1-month and 6-month mortality, respectively [6].

Patients with advanced choricocarcinoma have a worse prognosis than do the patients with other advanced/poor prognosis non-seminomatous GCTs because of the very high levels of hCG and the propensity for pulmonary and non-pulmonary visceral metastases [8]. Jensen and Venner [9] presented data from a population of 77 advanced germ cell patients who were treated with cisplatin-based therapy, and 3 of 77 patients had pure choriocarcinoma. All the three patients with pure choriocarcinoma died. The recurrent pure choriocarcinoma also has a very poor prognosis. There has been a report on a large series from Indiana University of 135 patients with GCTs and these patients failed after the first-line, platinum-based therapy, and the patients were treated with standard salvage chemotherapy with vinblastine, ifosfamide and cisplatin. Thirty-two patients were long-term survivors, but all the seven choriocarcinoma syndrome patients died . However, Papiani and Einhorn [9] reported that long-term survival and a potential cure was possible with high-dose chemotherapy in the patients with recurrent choriocarcinoma. The patients with choriocarcinoma who fail to achieve a complete response $(\mathrm{CR})$ to the first-line therapy (the so-called incomplete responders) have a less than a $10 \%$ likelihood of long-term survival with the second-line chemotherapy $[10,12]$. We could not follow up the patient regarding response to the chemotherapy as he was transferred to a cancer institute for further treatment. 


\section{References}

1. Dahnert W. Radiology review manual. 5th ed. Williams and Wilkins; 2003. (2010). Testicular tumour. 925. Alshyarba MH. A giant intra-abdominal testicular seminoma. Biomed Res, 21: 227-229.

2. Cristian PC, Cristobel B, Macaroni R. (2007). New case of an intra-abdominal testicular seminoma in an adult. Actus Uro Esp, 31: 160-163.

3. Cheville JC. (1999). Classification and pathology of testicular germ cell and sex cord-stromal tumors. Urol Clin North Am, 26:595-609.

4. Mostofi FK. (1973). Proceedings: Testicular tumors. Epidemiologic, etiologic, and pathologic features. Cancer, 32:1186-1201.

5. Yokoi K, Tanaka N, Furukawa K, Ishikawa N, Seya T, Horiba K, et al. (2008). Male choriocarcinoma with metastasis to the jejunum: a case report and review of the literature. J Nippon Med Sch, 75:116-121.

6. American Joint Committee on Cancer. Testis. In: AJCC Cancer Staging Manual. 6th edition. New York: Springer Science Business Media LCC; 2006.
7. Bosl GJ, Chaganti RS. (1994). the use of tumor markers in germ cell malignancies. Hematol Oncol Clin North Am, 8(3):573-87.

8. J Clin Oncol. (1997). International Germ Cell Cancer Collaborative Group. International Germ Cell Consensus Classification: a prognostic factor- based staging system for metastatic germ cell cancers, 15 (2):p594-603.

9. Einhorn LH, Williams SD, Chamness A, et al. (2007). High-dose chemotherapy and stem-cell rescue for metastatic germ-cell tumors. N Engl J Med, 357(4):p340-8.

10. Van Dijk MR, Steyerberg EW, Habbema JD. (2006). Survival of non-seminomatous germ cell cancer patients according to the IGCC classification: An update based on meta-analysis. Eur J Cancer, 42(7):820-6.

11. Robert S. Davidson, Chukwumere E. Nwogu, Mathijs J. Brentjens, Timothy M. Anderson. (2001). Surgical Oncology, 10 $35-42$.

12. Van Dijk MR, Steyerberg EW, Habbema JD. (2006). Survival of non-seminomatous germ cell cancer patients according to the IGCC classification: An update based on meta-analysis. Eu J Cancer, 42(7):820-6.
This work is licensed under Creative Commons Attribution 4.0 License

To Submit Your Article Click Here: Submit Manuscript

DOI: $10.31579 / 2690-1897 / 017$
Ready to submit your research? Choose Auctores and benefit from:

* fast, convenient online submission

* rigorous peer review by experienced research in your field

* rapid publication on acceptance

* authors retain copyrights

* unique DOI for all articles

* immediate, unrestricted online access

At Auctores, research is always in progress.

Learn more www.auctoresonline.org/journals/surgical-case-reports-andimages 